\title{
Uveitis: report of a 5-year survey
}

\author{
D. Geraint JAMES \\ M.A., M.D. (Cantab.), F.R.C.P. (London) \\ Consultant Physician \\ P. M. A. BOWDEN \\ L.R.C.P. (London), M.R.C.S. (England)
}

Senior House Officer

Medical Ophthalmology Unit, Royal Eye Hospital, London, S.E.1

\author{
D. G. FLECK
}

M.D. (London), M.C.Path.

\section{Director}

Public Health Laboratory, St George's Hospital, Tooting Grove, London, S.W.17

\author{
A. I. FriedmanN \\ F.R.C.S. (England) \\ Consultant Surgeon
}

A. N. BowDEN

B.Sc. (London), M.R.C.P. (London)

Medical Registrar

\begin{abstract}
Summary
During the first 5 years (1963-67) of a new Medical Ophthalmology Unit, 204 of the 1700 admissions had endogenous uveitis. It was anterior in $141(70 \%)$, posterior in thirty-three $(16 \%)$ and generalized in thirty $(14 \%)$.
\end{abstract}

Acute uveitis in ninety-seven patients ended in the course of months whereas chronic uveitis in 107 was measured over the years, punctuated by relapses.

Sex distribution was equal, and the age at apparent onset of the first incident was evenly spaced in the third to sixth decades, with a mean age of 39 years (range 6-77). Uveitis, observed in twenty children of either sex, was more commonly posterior and chronic.

Clinical accompaniments of adult uveitis include rheumatoid arthritis, ankylosing spondylitis, respiratory infections, toxoplasmosis, sarcoidosis and helminth infestations in that order of frequency. No accompanying abnormality could be detected by clinical examination, radiology, haematology or other investigations in ninety-two $(45 \%)$ patients.

It seems that widely cast investigative routines are not worthwhile in view of this poor return, and that instead, a few tests, selected by the clinico-radiological circumstances, might be equally fruitful. For instance, the Kveim-Siltzbach test is helpful in delineating sarcoid uveitis and the toxoplasma dye test in defining one form of posterior uveitis. In this series, the toxoplasma dye test titre was positive significantly more often in posterior than in anterior uveitis, and this was more evident in Negroes rather than Caucasians. Three-quarters of Negroes with choroiditis had toxoplasma dye test titres of $1: 16$ and above.

\section{Introduction}

On 1 January 1963 a new Medical Ophthalmology Unit was instituted and staffed by physicians with a special interest in ophthalmology, and by ophthalmic surgeons. During the first 5 years (1963-67) there were 1700 in-patient admissions, including 599 (35\%) patients with vascular disease, $566(33 \%)$ neurological problems, and $279(16 \%)$ with inflammatory ocular disease (Table 1). Uveitis accounted for 244

TABLe 1. Diagnostic groups of admissions to the Medical Ophthalmology Unit during the 5-year period 1963-67

\begin{tabular}{|c|c|c|c|c|}
\hline Diagnostic group & No. & & & $\%$ \\
\hline $\begin{array}{l}\text { Vascular } \\
\text { Diabetes }\end{array}$ & 599 & 52 & 35 & 3 \\
\hline $\begin{array}{l}\text { Neurological } \\
\text { Retrobulbar neuritis } \\
\text { Cranial nerve palsy }\end{array}$ & 566 & $\begin{array}{r}109 \\
80\end{array}$ & 33 & $\begin{array}{l}6 \\
5\end{array}$ \\
\hline $\begin{array}{l}\text { Inflammatory } \\
\text { Uveitis }\end{array}$ & 279 & 244 & 16 & 14 \\
\hline $\begin{array}{l}\text { Endocrine } \\
\text { Exophthalmos }\end{array}$ & 80 & 52 & 5 & 3 \\
\hline Miscellaneous & 176 & & 11 & \\
\hline Total & 1700 & & 100 & \\
\hline
\end{tabular}

$(14 \%)$ of these admissions; forty patients had exogenous uveitis and this report restricts itself to an analysis of the remaining 204 patients with endogenous uveitis. 


\section{Patients and methods}

All 244 patients had uveitis which was sufficiently troublesome to warrant in-patient investigation and treatment in the special twenty-bedded Royal Eye Hospital Medical Ophthalmology Unit located at Lambeth Hospital. The patients were examined by a staff which included an ophthalmic surgeon and a general physician interested in inflammatory eye disease. Routine investigations included radiography of the chest, lumbar spine, sacro-iliac joints and hands; blood picture, sedimentation rate, toxoplasma dye tests, serological antibody titres for typhoid fever, brucellosis and gonorrhoea; rheumatoid factor, blood Wassermann and Kahn reactions; blood calcium, phosphate and alkaline phosphatase levels; tuberculin tests; 24-hr urine calcium levels; and cultures of mid-stream urine specimens. Special tests such as the Kveim-Siltzbach, histoplasmin, blastomycin and coccidioidin skin tests were done when indicated. Serological tests for circulating antibodies against influenza, the psittacosis group, adenovirus, mumps, herpes simplex, the respiratory syncytial agent and Mycoplasma pneumoniae were done in 110 patients with uveitis and in thirty-one control subjects of similar age and sex admitted to the Unit. Bacterial respiratory infections were confirmed by isolation of the organism from sputa.

Anterior uveitis is regarded synonymously with iritis or iridocyclitis, and posterior uveitis with choroidoretinitis, whereas generalized uveitis indicated involvement of both posterior and anterior segments of the eye. Acute uveitis was abrupt in onset, and its duration, including relapses, was measurable in months. Chronic uveitis had an insidious onset, a duration of over 12 months, and a course punctuated by remissions and relapses over many years.

\section{Results}

\section{Types of uveitis}

Uveitis was anterior in $141(70 \%)$, posterior in thirty-three $(16 \%)$ and generalized in thirty $(14 \%)$ patients (Table 2). It was bilateral in eighty-five (42\%

TABLE 2. Main clinical features in 204 patients with uveitis

\begin{tabular}{lrr}
\hline \multicolumn{1}{c}{ Uveitis } & No. & $\%$ \\
\hline Male & 102 & 50 \\
Bilateral & 85 & 42 \\
Anterior & 141 & 70 \\
Posterior & 33 & 16 \\
Generalized & 30 & 14 \\
Total & 204 & 100 \\
\hline
\end{tabular}

patients. Uveitis was acute in ninety-seven and chronic in 107 patients (Table 3). The duration of acute uveitis was measured in months, lasting 1
TABLE 3. Correlation between the type and location of uveitis

\begin{tabular}{lrrrrrr}
\hline \multirow{2}{*}{ Uveitis } & \multirow{2}{*}{ No. } & \multicolumn{2}{c}{ Acute } & & \multicolumn{2}{c}{ Chronic } \\
\cline { 3 - 4 } \cline { 6 - 7 } \cline { 6 - 7 } & & No. & $\%$ & & No. & $\%$ \\
\hline Anterior & 141 & 70 & 50 & & 71 & 50 \\
Posterior & 33 & 15 & 45 & & 18 & 55 \\
Generalized & 30 & 12 & 40 & & 18 & 60 \\
Total & 204 & 97 & 48 & & 107 & 52 \\
\hline
\end{tabular}

month in one-half and 3 months in three-quarters of patients. In contrast, chronic uveitis was measured over the course of 20 years or so.

\section{Sex and age}

Sex distribution was equal, for men composed 102 of 204 patients. The age at apparent onset of the first incident of uveitis was evenly spaced in the third to sixth decades of life, with a mean age of 39 years (range 6-77). Uveitis was only observed in twenty children, ranging in age from 6 to 16 years, the mean age at onset of symptoms being 12.4 years. Sex incidence was equal in childhood uveitis, which was more commonly posterior and chronic than in adults (Table 4).

TABLE 4. The main features of uveitis in children

\begin{tabular}{lrr}
\hline \multicolumn{1}{c}{ Uveitis } & No. & $\%$ \\
\hline Male & 10 & 50 \\
Acute & 8 & 40 \\
Chronic & 12 & 60 \\
Anterior & 14 & 70 \\
Posterior & 6 & 30 \\
Total & 20 & 100 \\
\hline
\end{tabular}

\section{Clinical accompaniments}

A group of forty-one patients with demonstrable exogenous uveitis included herpes zoster in twenty, trauma in fourteen and herpes simplex keratitis in seven patients (Table 5). They are not considered

TABLE 5. Diagnostic categories of 279 patients with inflammatory ocular disease

\begin{tabular}{lrr}
\hline Inflammatory ocular disease & \multicolumn{2}{c}{ No. } \\
\hline Endogenous uveitis & 204 & \\
Exogenous uveitis & 41 & 20 \\
$\quad$ Herpes ophthalmicus & & 14 \\
$\quad$ Trauma & & 7 \\
$\quad$ Herpes simplex keratitis & 17 & \\
Retinal vasculitis & 7 & \\
Scleritis & 3 & \\
Exudative retinitis (Coats') & 3 & \\
Conjunctivitis & 2 \\
Orbital cellulitis & 1 \\
Dacryoadenitis & 1 \\
Sjogren's syndrome & 279 \\
Total & \\
\hline
\end{tabular}


further in the present report. Associated abnormalities in the remaining 204 with endogenous uveitis included rheumatoid arthritis or ankylosing spondylitis in thirty-two $(16 \%)$, respiratory infections in thirteen $(6 \%)$, toxoplasmosis in eleven $(5 \%)$, sarcoidosis in eight $(4 \%)$ and helminth infestations in five (Table 6). Even more important is the fact that

TABLE 6. Recognizable associated disorders in 204 patients with endogenous uveitis

\begin{tabular}{lrr}
\hline \multicolumn{1}{c}{ Uveitis } & No. & $\%$ \\
\hline Ankylosing spondylitis & 16 & 8 \\
Rheumatoid arthritis & 16 & 8 \\
Respiratory infections & 13 & 6 \\
Toxoplasmosis & 11 & 5 \\
Sarcoidosis & 8 & 4 \\
Venereal disease & 8 & 4 \\
Helminth infestations & 5 & 2 \\
Multiple sclerosis & 3 & $>2$ \\
Brodie-Reiter syndrome & 2 & \\
Uveoencephalitic syndrome & 2 & \\
Psoriasis & 2 & \\
Total & 86 & 42 \\
\hline
\end{tabular}

no accompanying abnormality could be detected by clinical examination, radiology, haematology or other current investigations in ninety-two patients $(45 \%)$.

The most commonly recognized association was a rheumatic disorder. Rheumatoid arthritis and ankylosing spondylitis were associated with characteristic clinical patterns, suggestive radiology and positive serological tests. They were often associated with chronic relapsing anterior uveitis rather than with acute uveitis or choroido-retinitis. Sarcoid uveitis in eight patients was delineated by a characteristic chest $\mathrm{X}$-ray abnormality, negative tuberculin test, positive Kveim-Siltzbach test and by organ biopsy. Bacterial respiratory tract infections in thirteen instances were associated with a flare-up of chronic anterior uveitis. Other infections associated with non-specific uveitis included helminths in five, gonorrhoea (four), syphilis (three) and chancroid in one patient; seven of the venereal infections were associated with acute anterior and one with chronic uveitis. Coccidioidin, blastomycin and histoplasmin skin tests were negative in forty-seven patients. Serological complementfixation and neutralization tests for circulating antibodies against certain viruses, $\mathrm{Q}$ fever and Mycoplasma pneumoniae were often positive in both uveitis and control patients (Table 7). They did not occur more often in uveitis patients; if anything the reverse held true.

\section{Toxoplasmosis}

Positive toxoplasma dye tests at a level of $1: 16$ or more were observed in forty-nine $(24 \%)$; Negroes $(53 \%)$ had a higher incidence of positive tests than Caucasians $(20 \%)$ (Table 8$)$. A positive dye test titre
TABLE 7. Incidence of serological antibodies in 110 patients with uveitis and thirty-one control patients

\begin{tabular}{lrrrrr}
\hline & \multicolumn{3}{c}{ Positive in: } \\
\cline { 2 - 3 } Serological antibodies against & \multicolumn{2}{c}{ Uveitis } & & \multicolumn{2}{c}{ Controls } \\
\cline { 2 - 3 } \cline { 5 - 6 } & No. & $\%$ & & No. & $\%$ \\
\hline Influenza A & 22 & 20 & & 18 & 58 \\
Influenza B & 13 & 12 & & 8 & 26 \\
Psittacosis & 9 & 8 & & 3 & 9 \\
Q fever & 0 & 0 & & 0 & 0 \\
Adenovirus & 15 & 14 & & 6 & 20 \\
Mumps V & 41 & 37 & & 20 & 65 \\
Herpes simplex & 27 & 25 & & 14 & 45 \\
Mycoplasma pneumoniae & 6 & 6 & & 4 & 13 \\
Respiratory syncytial & 19 & 17 & & 11 & 36 \\
\hline
\end{tabular}

TABLE 8. Relationship between race, type of uveitis and toxoplasma dye test titres of $1: 16$ and greater

\begin{tabular}{|c|c|c|c|c|c|c|}
\hline \multirow[t]{2}{*}{ Uveitis } & \multicolumn{2}{|c|}{$\begin{array}{l}\text { Caucasian } \\
\text { and Negro }\end{array}$} & \multicolumn{2}{|c|}{ Caucasian } & \multicolumn{2}{|c|}{ Negro } \\
\hline & No. & $\%$ & No. & $\%$ & No. & $\%$ \\
\hline $\begin{array}{l}\text { Anterior } \\
\text { Generalized } \\
\text { Posterior }\end{array}$ & $\begin{array}{r}22 \\
8 \\
19\end{array}$ & $\begin{array}{l}15 \\
30 \\
60\end{array}$ & $\begin{array}{r}19 \\
6 \\
13\end{array}$ & $\begin{array}{l}14 \\
24 \\
52\end{array}$ & $\begin{array}{l}3 \\
2 \\
6\end{array}$ & $\begin{array}{l}43 \\
33 \\
75\end{array}$ \\
\hline Total & 49 & 24 & 38 & 20 & 11 & 53 \\
\hline
\end{tabular}

was noted in six of eight Nigerians, four of ten West $\varnothing$ Indians, and one of three Ghanaians. Positive dye test titres were far more commonly associated witho posterior than anterior uveitis. Choroiditis was sig- $?$ nificantly more often associated with positive toxoplasma dye test titres than anterior uveitis $(P=0.005$ in the third decade). The presence of choroidoretinitis in the Negro is a particular indication for doing the toxoplasma dye test.

\section{Discussion}

This series of 204 patients with endogenous uveitis is selected in the sense that the disorder was so troublesome that patients were admitted as inpatients for the facilities of a specialized Medical Ophthalmology Unit. Despite a widely cast net of investigations, no abnormality other than uveitis was found in nearly half of these patients, an experience shared by others (Otto, 1964). In the remainder some abnormality was noted either on physical examination, by X-rays or blood tests or by some biochemical upset or skin test. It is questionable whether our present investigative routine is worthwhile in view of this poor return. Instead a few tests, selected by the clinical and radiological circumstances, might be equally or more fruitful; for instance, toxoplasma dye test titres are useful in defining posterior uveitis (Perkins, 1961) and in this series choroiditis was significantly more often associated with positive tests than anterior uveitis 
TABLE 9. Various skin and blood tests, X-rays and histology found helpful in the investigation of uveitis.

\begin{tabular}{llll}
\hline \multicolumn{1}{c}{ Skin } & \multicolumn{1}{c}{ Blood } & Radiography & Histology \\
\hline Tuberculin & Toxoplasma dye & Chest & Conjunctiva \\
& Autoantibodies & Spine & Lacrimal gland \\
& Latex & Sacro-iliacs & Ankles \\
Oral mucosa & Hiver & \\
Dinitrochlorobenzene & Mycoplasma CFT & Hands & \\
Kveim-Siltzbach & Cold agglutinins & & \\
& Wassermann & & \\
Toxocara & Leucocyte count & & \\
& ESR & & \\
\hline
\end{tabular}

The selection depends upon circumstances, including clinical features; race, age and sex of the patient; type of uveitis; and chest X-ray findings.

( $P=0.005$ in the third decade). The incidence of positive tests in Caucasians and Negroes considered separately reflects the expected incidence; in Britain the incidence is $19 \%$ (Fleck, 1963), compared with an incidence of $60 \%$ at a titre of $1: 8$ or more in Africa (Ludlam, 1965) and $53 \%$ at a titre of $1: 4$ or more in the West Indies (Lunde \& Jacobs, 1958). The presence of choroido-retinitis in the Negro is a good reason for seeking serological antibody titres by the toxoplasma dye test (Table 8).

The selection of tests will depend upon clinical features, race, age, sex, type of uveitis and chest $\mathrm{X}$-ray findings. They can be subdivided into skin tests, blood tests, radiographic techniques, histology and examination of faeces (Table 9).

\section{Skin tests}

Depression of delayed-type hypersensitivity may be established by a negative tuberculin test and by lack of sensitization to dinitrochlorobenzene. The Kveim-Siltzbach test is of considerable value in delineating sarcoid uveitis in women of the childbearing period of life (Anderson et al., 1963; James et al., 1964). A toxocara skin test is likewise being developed to detect those, particularly children, who have been infested by toxocara.

\section{Blood tests}

The toxoplasma dye test is of value in defining one cause of choroido-retinitis, and it is evident from this series that further surveys with this test need to be done particularly in migrants with uveitis.

Serological tests for anti-uveal antibodies were not done, and present techniques do not provide encouraging results. Dieckhaus (personal communication 1967), working in Munster, sought anti-uveal antibodies by haemagglutination, complementfixation and precipitin techniques, in 204 patients with chronic uveitis, thirty-two with acute uveitis and in eighty-three control sera. Positive titres were obtained by one or other techniques in up to $20 \%$ of control sera and in a similar percentage of uveitis patients. The margin of difference was not sufficiently distinctive to be of practical value, and at variance with results noted by Perkins \& Woods (1964). Lehner (1966) has distinguished iritis due to Behçet's syndrome by finding haemagglutinating antibodies against oral mucosa in $80 \%$ of patients. These findings are sufficiently encouraging to include the test in any future investigative routine for uveitis.

Clinical evidence suggestive of the StevensJohnson syndrome is an indication for seeking cold agglutinins and the mycoplasma complement-fixation test.

Syphilitic uveitis was found in only three of 204 patients in this series, so the investigative value of the Wassermann reaction is limited. A routine leucocyte count may disclose eosinophilia, which in itself is an indication for examination of the faeces for helminth infestation. A polymorphonuclear leucocytosis suggests bacterial infection, whereas a relative lymphocytosis points to a virus infection or possibly tuberculosis. A grossly elevated sedimentation rate would suggest a collagen disorder or, depending upon the age, temporal or giant cell arteritis with associated retinal vaculitis.

\section{Radiography}

Chest radiography should be routine in all patients, for evidence of sarcoidosis and infections. The association of anterior uveitis with rheumatoid arthritis and ankylosing spondylitis is so close that the correct selection of X-rays is dictated by the patient's symptoms. X-ray evidence for calcaneal spurs should be considered in men with non-specific urethritis.

\section{Histology}

Depending upon circumstances, histology of conjunctiva, lacrimal gland, scalene node or liver may be particularly fruitful (Table 9).

\section{Treatment}

The purpose of defining the aetiology of uveitis is largely in order to treat it more accurately. 
Specific antimicrobial therapy is available for some causes, such as brucellosis, leprosy and mycoplasma infection, and a new era of antiviral chemotherapy was ushered by 5-iodo-deoxyuridine for herpes simplex infections. Other anti-viral agents will undoubtedly be developed and the ophthalmologist must be ready to use them judiciously. For the present, the mainstay of the treatment of uveitis comprises dilatation of the pupil and local and systemic corticosteroids.

\section{References}

Anderson, R., James, D.G., Peters, P.M. \& Thomson, A.D (1963) The Kveim test in sarcoidosis. Lancet, ii, 650.
FleCK, D.G. (1963) Epidemiology of toxoplasmosis. J. Hyg. (Camb.), 61, 61.

James, D.G., Anderson, R., Langley, D. \& Ainslie, D. (1964) Ocular sarcoidosis. Brit. J. Ophthal. 48, 461.

LEHNER, T.E. (1967) Behçet's syndrome and autoimmunity. Brit. med. J. 1, 465.

LudLAM, G.B. (1965) Toxoplasma antibodies in inhabitants of Niger delta. Trans. R. Soc. trop. Med. Hyg. 59, 83.

LUNDE, M.N. \& JACOBS, L. (1958) A comparison of results of haemagglutination and dye tests for toxoplasmosis in a survey of Trinidad natives. Amer. J. trop. Med. Hyg. 7, 523.

Orтo, J. (1964) Die bedeutung latenter infekte für Atiologie und therapie chronischer intraokularer erkrankungen. Klin. Mbl. Augenheilk, 145, 801.

Perkins, E.S. (1961) Uveitis and Toxoplasmosis. Churchill, London.

Perkins, E.S. \& Woods, R.M. (1964) Autoimmunity in uveitis. Brit. J. Ophthal. 48, 61. 